\title{
Article
}

\section{The Influence of the Environment on the Properties of Hybrid Cement-Based Concrete with Steel and Air-Cooled Slags}

\author{
Pavel Martauz ${ }^{1}$, Vojtěch Václavík ${ }^{2, *(1)}$ and Branislav Cvopa ${ }^{1}$ \\ 1 Cement Plant-Považská Cementáreň, a.s., 01863 Ladce, Slovakia; martauz.p@pcla.sk (P.M.); \\ cvopa.b@pcla.sk (B.C.) \\ 2 Department of Environmental Engineering, Faculty of Mining and Geology, VSB - Technical University of \\ Ostrava, 17. Listopadu 15/2172, 70800 Ostrava, Czech Republic \\ * Correspondence: vojtech.vaclavik@vsb.cz; Tel.: +420-596-993-377
}

Citation: Martauz, P.; Václavík, V.; Cvopa, B. The Influence of the Environment on the Properties of Hybrid Cement-Based Concrete with Steel and Air-Cooled Slags. Crystals 2021, 11, 1087. https://doi.org/ $10.3390 /$ cryst11091087

Academic Editors: Luis G. Baltazar and Shima Pilehvar

Received: 19 August 2021

Accepted: 2 September 2021

Published: 7 September 2021

Publisher's Note: MDPI stays neutral with regard to jurisdictional claims in published maps and institutional affiliations.

Copyright: (c) 2021 by the authors. Licensee MDPI, Basel, Switzerland. This article is an open access article distributed under the terms and conditions of the Creative Commons Attribution (CC BY) license (https:// creativecommons.org/licenses/by/ $4.0 /)$.

\begin{abstract}
This article presents the results of research that dealt with the development of nontraditional concrete using a hybrid alkali-activated cement. It is concrete based on by-products from a metallurgical plant that replaced $100 \%$ of the natural aggregates. Steel slag (CSS, fraction: $0 / 8 \mathrm{~mm}$ ) was used as a filler in combination with air-cooled slag (ACBFS, fraction: 8/16 mm and 16/32 mm). Portland blended cement (CEM II/B-S 42.5N) and H-CEMENT were used as binding components in the development of the concrete mixture designs. Both of these cements were produced by Považská cementáreň, a.s., Ladce. Attention was focused on testing the physical and mechanical properties of the developed concretes in various environments. An aqueous environment was selected as the first environment for the placement of test specimens (cubes with $150 \mathrm{~mm}$ edges and prisms with dimensions of $100 \times 100 \times 400 \mathrm{~mm}^{3}$ ) according to the ČSN EN 206-1 standard and the outdoor environment (August to October). The determination of the cube strength was made after 7,28 , and 90 days, the determination of the flexural and compressive strength was made at the end of the prisms, and the determination of the dynamic modulus of elasticity was made after 28 days on the prisms. The test results of the test specimens, which were placed in two environments, were compared and it was found that, after 90 days, the outdoor environment caused a decrease in the concrete's strength characteristics when using Portland blended cement (CEM II/ B-S 42.5N) of about $8 \%$; in contrast, when using H-CEMENT, the concrete's strength increased by about $14 \%$. The use of H-CEMENT and the addition of PUZZOLANIT in the amount of $30 \%$ in combination with CEM II/B-S $42.5 \mathrm{~N}$ in the amount of $70 \%$ reduced the decrease in the strength of the concrete after 90 days by about $3 \%$. The research results confirm the suitability of using H-CEMENT and the addition of PUZZOLANIT for the production of concrete based on steel slag (CSS) and air-cooled slag (ACBFS).
\end{abstract}

Keywords: steel slag; air cooled slag; concrete; sustainable material; influence; environment; mechanical and physical properties

\section{Introduction}

The use of industrial by-products in concrete is a hot topic being addressed both on a European and a global scale [1]. The greatest attention in concrete technology is focused on the replacement of natural aggregates by by-products in order to protect and preserve the exhaustible natural resources of aggregates. Our experimental research was focused on the development of concrete mixture designs with $100 \%$ replacement of natural aggregates of fraction $0 / 32 \mathrm{~mm}$ by steel slag of fraction $0 / 8 \mathrm{~mm}$ and air-cooled slag (ACBFS) of fraction $8 / 16$ and $16 / 32 \mathrm{~mm}$. We based the development of the experiment on our own research experience and pilot applications, where we have used steel slag of fraction $0 / 8 \mathrm{~mm}$ as a replacement for $100 \%$ of the natural aggregates in combination with H-CEMENT [2]. Based on the performed tests, H-CEMENT proved to be a suitable binder for concrete 
based on by-products from a metallurgical plant. At present, we know the results of research that used slag from electric arc furnaces of fractions $0 / 5,5 / 12$, and $12 / 25 \mathrm{~mm}$ as a partial replacement of natural aggregates in the production of concrete [3-11]. The usage of steel-reducing slag with a specific surface area of 1766 and $7970 \mathrm{~cm}^{2} / \mathrm{g}$ in the production of self-compacting concretes as a replacement for the filler binder is described in [12]. The results of the research that dealt with the mechanical activation of stainless steel slags with subsequent use as a hydraulic binder are described in [13]. In his study [14], Dong compiled an overview of the use of steel slag in Portland-cement-based concrete. Another overview of the application of steel slag in cement and concrete technology is given in [15].

Blast furnace granulated slag has a wide range of applications in concrete technology. An important area of application of finely ground blast furnace slag is alkali-activated concrete with a strength of 20-80 MPa [16-18]. Furthermore, it is possible to use finely ground blast furnace slag in combination with fly ash as a binder substitute in concretes based on by-products (foundry sands, fine recycled aggregates) [19]. It is also possible to use the blast furnace granulated slag in combination with recycled concrete aggregates for self-compacting concrete [20]. The results of research dealing with the replacement of natural coarse aggregates in the amount of 25,50 , and $100 \%$ by blast furnace granulated slag and electric arc furnace slag (EAFS) in the production of concrete are also known [7].

Another possibility for replacing natural aggregates in the production of concrete is the use of recycled aggregates, which can be obtained from construction waste. This replacement can be used for low-to-medium strength concretes that will not be exposed to aggressive environments. The results of the research in this field are described in [21-24]. Methods for treating recycled aggregates with $\mathrm{CO}_{2}$ in order to increase the density and reduce the absorbency are also known [23-25].

The influence of fluctuations in the temperature and humidity regimes of the environment contributes to shortening the service life of concrete structures. Long-term tests (90 days, 180 days, 365 days, 5 years, 10 years) of test specimens and concrete structures in situ are required to demonstrate these effects on reducing the service life of concrete structures, since modeling an outdoor environment on a laboratory scale can be difficult. The most common tests of concrete structures and test specimens located in an outdoor environment are: strength characteristics, depth of carbonation, and depth of penetration of chloride ions [26]. Long-term tests of the depth of penetration of chloride ions are performed on concretes that are exposed to seawater [25]. In our experiment, we focused on the change in the strength characteristics of non-traditional concrete based on steel slag and ACBFS due to the environment. The test specimens were placed in an aqueous and outdoor environment for 7,28 , and 90 days and subsequently subjected to tests of strength characteristics.

\section{Materials and Methods}

\subsection{Steel Slag and Artificial Aggregates}

Steel slag is formed as a by-product in the treatment of pig iron in primary and secondary metallurgy [26]. Slag produced in different steel plants has different properties. The main chemical components include $\mathrm{CaO}, \mathrm{SiO}_{2}, \mathrm{Fe}_{2} \mathrm{O}_{3}, \mathrm{MgO}, \mathrm{Al}_{2} \mathrm{O}_{3}, \mathrm{MnO}$, and $\mathrm{P}_{2} \mathrm{O}_{5}$. The chemical composition of steel slag varies according to the type of furnace, the quality of the steel, and the method of preparation. Table 1 presents the chemical composition of steel slag from basic oxygen furnace slag (BOFS) and EAFS. The mineralogical composition of steel slag is variable. The proportion of crystalline phase and glass depends on the crystallization rate of the slag. The following minerals are present in steel slags: dicalcium silicate, $\mathrm{C}_{2} \mathrm{~S}$; tricalcium silicate, $\mathrm{C}_{3} \mathrm{~S}$; dicalcium ferrite, $\mathrm{C}_{2} \mathrm{~F}$; tetracalcium aluminoferrite, $\mathrm{C}_{4} \mathrm{AF}$; acermanite; gehlenite; periclase $\mathrm{MgO}$; and free $\mathrm{CaO}[27,28]$.

Converter steel slag of fraction $0 / 8 \mathrm{~mm}$ was used for our experimental design. The chemical composition of this steel slag is presented in Table 2. 
Table 1. Chemical composition of steel slag.

\begin{tabular}{ccccccccc}
\hline Oxides (\%) & $\mathbf{C a O}$ & $\mathbf{S i O}_{\mathbf{2}}$ & $\mathbf{A l}_{\mathbf{2}} \mathbf{O}_{\mathbf{3}}$ & $\mathbf{F e}_{\mathbf{2}} \mathbf{O}_{\mathbf{3}}$ & $\mathbf{F e O}$ & $\mathbf{M g O}$ & $\mathbf{M n O}$ & $\mathbf{P}_{\mathbf{2}} \mathbf{O}_{5}$ \\
\hline BOFS & $45-60$ & $10-15$ & $1-5$ & $3-9$ & $7-20$ & $3-13$ & $2-6$ & $1-4$ \\
EAFS & $30-50$ & $11-20$ & $10-18$ & $5-6$ & $8-22$ & $8-13$ & $5-10$ & $2-5$ \\
\hline
\end{tabular}

Table 2. Chemical composition of converter steel slag (CSS) of fraction 0/8 mm [29].

\begin{tabular}{|c|c|c|c|c|c|c|c|}
\hline Analyte & Unit & Result & Uncertainty & Analyte & Unit & Result & Uncertainty \\
\hline $\mathrm{Na}_{2} \mathrm{O}$ & weight \% & 0.46 & \pm 0.10 & $\mathrm{~V}$ & $\mathrm{mg} / \mathrm{kg}$ & 570 & - \\
\hline $\mathrm{MgO}$ & weight $\%$ & 10.2 & \pm 1.2 & $\mathrm{Cr}$ & $\mathrm{mg} / \mathrm{kg}$ & 3900 & - \\
\hline $\mathrm{Al}_{2} \mathrm{O}_{3}$ & weight $\%$ & 2.43 & \pm 0.27 & $\mathrm{Ni}$ & $\mathrm{mg} / \mathrm{kg}$ & 25 & - \\
\hline $\mathrm{SiO}_{2}$ & weight \% & 13.7 & \pm 1.3 & $\mathrm{Cu}$ & $\mathrm{mg} / \mathrm{kg}$ & 38 & - \\
\hline $\mathrm{P}_{2} \mathrm{O}_{5}$ & weight $\%$ & 0.91 & \pm 0.09 & $\mathrm{Zn}$ & $\mathrm{mg} / \mathrm{kg}$ & 63 & - \\
\hline $\mathrm{SO}_{3}$ & weight $\%$ & 0.50 & \pm 0.06 & $\mathrm{Sr}$ & $\mathrm{mg} / \mathrm{kg}$ & 130 & - \\
\hline $\mathrm{K}_{2} \mathrm{O}$ & weight $\%$ & $<0.003$ & & $\mathrm{Zr}$ & $\mathrm{mg} / \mathrm{kg}$ & 140 & - \\
\hline $\mathrm{CaO}$ & weight $\%$ & 38 & \pm 2 & $\mathrm{Nb}$ & $\mathrm{mg} / \mathrm{kg}$ & 67 & - \\
\hline $\mathrm{TiO}_{2}$ & weight $\%$ & 0.29 & \pm 0.02 & Mo & $\mathrm{mg} / \mathrm{kg}$ & 36 & - \\
\hline $\mathrm{MnO}$ & weight $\%$ & 3.02 & \pm 0.13 & $\mathrm{Ba}$ & $\mathrm{mg} / \mathrm{kg}$ & 200 & - \\
\hline Fe total & weight \% & 22 & & Ta & $\mathrm{mg} / \mathrm{kg}$ & 110 & - \\
\hline $\mathrm{CaO}$ free & weight $\%$ & 2.34 & \pm 0.24 & W & $\mathrm{mg} / \mathrm{kg}$ & 86 & - \\
\hline- & - & - & - & $\begin{array}{l}\text { Loss by } \\
\text { annealing }\end{array}$ & weight $\%$ & -0.74 & - \\
\hline
\end{tabular}

Air-cooled slag (ACBFS) is one of the basic types of artificial aggregates. It is formed as a waste product in the production of iron. It is similar to natural igneous rocks. It is included in European technical standards together with aggregates from natural resources and is subject to the same normative requirements. Coarse artificial aggregate of $8 / 16$ and $16 / 32 \mathrm{~mm}$ was used for our experimental research. The chemical composition is given in Table 3.

Table 3. Chemical composition of ACBFS.

\begin{tabular}{crc}
\hline Chemical Composition & \multicolumn{2}{c}{ Result } \\
\hline $\mathrm{SiO}_{2}$ & $35-45 \%$ & $\varnothing 39 \%$ \\
$\mathrm{Al}_{2} \mathrm{O}_{3}$ & $5-10 \%$ & $\varnothing 8 \%$ \\
$\mathrm{MgO}$ & $5-15 \%$ & $\varnothing 9 \%$ \\
$\mathrm{CaO}$ & $35-45 \%$ & $\varnothing 37 \%$ \\
$\mathrm{CaO}$ free & $0.7-1.1 \%$ & $\varnothing 0.9 \%$ \\
\hline
\end{tabular}

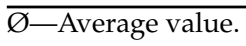

Table 4 presents the average values of properties of converter steel slag (CSS) of fraction $0 / 4 \mathrm{~mm}$ and $4 / 8 \mathrm{~mm}$ and air-cooled slag (ACBFS) of fraction $8 / 16 \mathrm{~mm}$ and 16/32 mm. Density and absorption capacity were determined according to EN 1097-6 [30], and the density in a tapped state and the porosity were determined according to EN 1097-3 [31].

All these fractions of converter steel slag (CSS) and (ACBFS) shown in Table 4 were subjected to granulometric analysis according to EN 933-1 [32]. Based on the performed tests and with the aid of C-Packing software, the optimal grain size curve of the combination of steel slag and ACBFS of fraction 0/32 mm was developed, which consists of CSS $0 / 4 \mathrm{~mm}$ $(32.0 \%)$, CSS $4 / 8 \mathrm{~mm}(18.0 \%)$, ACBFS 8/16 mm (20.0\%), and ACBFS $16 / 32 \mathrm{~mm}(30.0 \%)$. It follows from the above that the ratio of the filler-steel slag (CSS) and ACBFS is 50:50\%. Based on the results of the granulometric analysis (see Figure 1), the mean grain size was determined as $d_{50}$ from the individual grain size curves (see Table 5). 
Table 4. Properties of converter steel slag (CSS) and air-cooled slag (ACBFS).

\begin{tabular}{|c|c|c|c|c|}
\hline Artificial Aggregate & $\begin{array}{c}\text { CSS } \\
0 / 4 \mathrm{~mm}\end{array}$ & $\begin{array}{c}\text { CSS } \\
4 / 8 \mathrm{~mm}\end{array}$ & $\begin{array}{c}\text { ACBFS } \\
8 / 16 \mathrm{~mm}\end{array}$ & $\begin{array}{c}\text { ACBFS } \\
16 / 32 \mathrm{~mm}\end{array}$ \\
\hline Density $\left(\mathrm{kg} / \mathrm{m}^{3}\right)$ & 3294 & 3421 & 2636 & 2640 \\
\hline Loose bulk density-unshaken state $\left(\mathrm{kg} / \mathrm{m}^{3}\right)$ & 2047 & 1700 & 1479 & 1529 \\
\hline Loose bulk density—shaken state $\left(\mathrm{kg} / \mathrm{m}^{3}\right)$ & 2380 & 1970 & 1667 & 1767 \\
\hline Porosity-unshaken state $(\%)$ & 37.9 & 50.3 & 43.9 & 42.1 \\
\hline Porosity-shaken state $(\%)$ & 27.7 & 42.4 & 36.8 & 33.1 \\
\hline Water absorption $(\%)$ & 2.36 & 2.41 & 1.36 & 0.86 \\
\hline
\end{tabular}

Table 5. Medium grain size $d_{50}$.

\begin{tabular}{|c|c|c|c|c|c|}
\hline Artificial Aggregate & $\begin{array}{c}\text { CSS } \\
0 / 4 \mathrm{~mm}\end{array}$ & $\begin{array}{c}\text { CSS } \\
4 / 8 \mathrm{~mm}\end{array}$ & $\begin{array}{l}\text { ACBFS } \\
8 / 16 \mathrm{~mm}\end{array}$ & $\begin{array}{c}\text { ACBFS } \\
16 / 32 \mathrm{~mm}\end{array}$ & $\begin{array}{c}\mathrm{CSS}+\mathrm{ACBFS} \\
0 / 32 \mathrm{~mm}\end{array}$ \\
\hline Medium grain size $d_{50}(\mathrm{~mm})$ & 0.70 & 5.73 & 12.34 & 23.46 & 8.00 \\
\hline
\end{tabular}

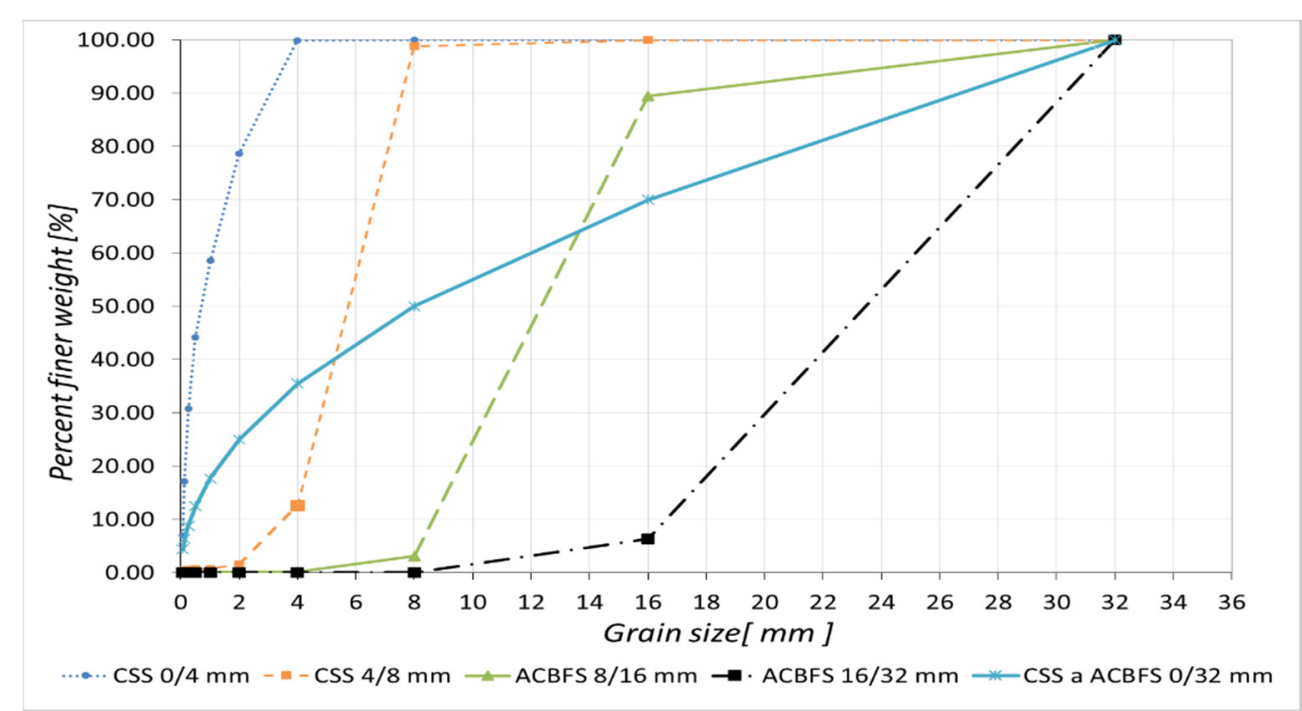

Figure 1. Granulometric curves of steel slag (CSS) and air-cooled slag (ACBFS).

\subsection{Cement, Additions, Water, Superplasticizer}

Two types of cement were used as a binder for the production of steel-slag-based concrete (CSS) and ACBFS. These were Portland blended cement (CEM II/B-S 42.5N) and hybrid cement denoted H-CEMENT. Both types of cements are produced by the company Považská cementáreň, a.s. Table 6 presents the chemical composition of the cements used and Table 7 presents their physical and mechanical properties.

Table 6. Chemical composition of cements.

\begin{tabular}{cccccccccc}
\hline Analyte (\%) & $\mathbf{N a}_{\mathbf{2}} \mathbf{O}$ & $\mathbf{M g O}$ & $\mathrm{Al}_{2} \mathbf{O}_{3}$ & $\mathbf{S i O}_{2}$ & $\mathbf{S O}_{3}$ & $\mathbf{C l}$ & $\mathbf{K}_{2} \mathbf{O}$ & $\mathrm{CaO}$ & $\mathbf{F e}_{2} \mathbf{O}_{3}$ \\
\hline H-CEMENT & 2.52 & 1.68 & 16.91 & 46.91 & 3.65 & 0.01 & 3.17 & 17.09 & 6.47 \\
CEM II/B-S 42.5N & 0.30 & - & - & - & 2.82 & 0.04 & 0.99 & - & - \\
\hline
\end{tabular}

Table 7. Physical and mechanical properties of cements.

\begin{tabular}{|c|c|c|c|c|c|c|c|}
\hline \multirow[t]{2}{*}{ Type of Cement } & \multirow{2}{*}{$\begin{array}{l}\text { Specific Surface Area } \\
\qquad\left(\mathrm{m}^{2} / \mathrm{kg}\right)\end{array}$} & \multirow{2}{*}{$\begin{array}{l}\text { Initial and Final Setting Time } \\
\text { (min.) }\end{array}$} & \multirow{2}{*}{$\begin{array}{l}\text { Density } \\
\left(\mathrm{kg} / \mathrm{m}^{3}\right)\end{array}$} & \multicolumn{2}{|c|}{$\begin{array}{l}\text { Compressive Strength } \\
\text { (MPa) }\end{array}$} & \multicolumn{2}{|c|}{$\begin{array}{c}\text { Flexural Strength } \\
\text { (MPa) }\end{array}$} \\
\hline & & & & 2 Days & 28 Days & 2 Days & 28 Days \\
\hline H-CEMENT & 696.8 & $230 / 285$ & 2770 & 14.9 & 39.0 & 4.1 & 7.8 \\
\hline CEM II/B-S 42.5N & 441.0 & $280 / 310$ & 3030 & 23.2 & 53.7 & 5.4 & 10.0 \\
\hline
\end{tabular}


A superplasticizer based on the modified polycarboxylate Sika ViscoCrete-4035 was used as an admixture for the production of a concrete mixture based on industrial waste.

Water from a tap water system was used as mixing water.

\subsection{Concrete Mixture Designs}

In order to verify the possibility of using steel slag (CSS) and ACBFS from blast furnace slag as a $100 \%$ substitute for natural aggregates of fraction $0 / 32 \mathrm{~mm}$, three concrete mixture designs were developed:

- C-A mix based on steel slag (CSS), which is represented by $0 / 4 \mathrm{~mm}\left(718 \mathrm{~kg}\right.$ per $\left.\mathrm{m}^{3}\right)$ and $4 / 8 \mathrm{~mm}\left(420 \mathrm{~kg}\right.$ per $\left.\mathrm{m}^{3}\right)$ and artificial dense aggregate from blast furnace slag (ACBSF) of fraction $8 / 16 \mathrm{~mm}\left(359 \mathrm{~kg}\right.$ per $\left.\mathrm{m}^{3}\right)$ and $16 / 32 \mathrm{~mm}\left(539 \mathrm{~kg}\right.$ per $\left.\mathrm{m}^{3}\right)$. The

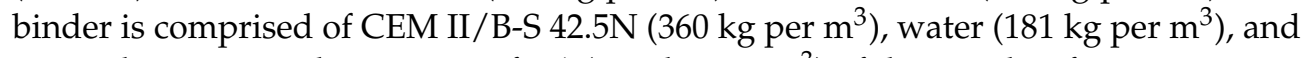
superplasticizer in the amount of $1 \%\left(3.25 \mathrm{~kg}\right.$ per $\left.\mathrm{m}^{3}\right)$ of the weight of cement.

- $\quad$ CH-A mix based on steel slag (CSS), which is represented by $0 / 4 \mathrm{~mm}\left(715 \mathrm{~kg}\right.$ per $\left.\mathrm{m}^{3}\right)$ and $4 / 8 \mathrm{~mm}\left(418 \mathrm{~kg}\right.$ per $\left.\mathrm{m}^{3}\right)$ and ACBFS of fraction $8 / 16 \mathrm{~mm}\left(358 \mathrm{~kg}\right.$ per $\left.\mathrm{m}^{3}\right)$ and $16 / 32 \mathrm{~mm}\left(537 \mathrm{~kg}\right.$ per $\left.\mathrm{m}^{3}\right)$. CEM II/BS $42.5 \mathrm{~N}\left(252 \mathrm{~kg}\right.$ per $\left.\mathrm{m}^{3}\right)$ is used as a binder, which is replaced in $30 \%$ by the addition of PUZZOLANIT (H-CEMENT) $\left(108 \mathrm{~kg} \mathrm{per} \mathrm{m}^{3}\right)$, water $\left(181 \mathrm{~kg}\right.$ per $\left.\mathrm{m}^{3}\right)$, and plasticizer in the amount of $1.1 \%\left(4.0 \mathrm{~kg}\right.$ per $\left.\mathrm{m}^{3}\right)$ of the weight of cement.

- $\quad \mathbf{H}-\mathrm{A}$ mix based on steel slag (CSS), which is represented by $0 / 4 \mathrm{~mm}\left(707 \mathrm{~kg}\right.$ per $\left.\mathrm{m}^{3}\right)$ and $4 / 8 \mathrm{~mm}\left(413 \mathrm{~kg}\right.$ per $\left.\mathrm{m}^{3}\right)$ and ACBFS of fraction $8 / 16 \mathrm{~mm}\left(353 \mathrm{~kg}\right.$ per $\left.\mathrm{m}^{3}\right)$ and $16 / 32 \mathrm{~mm}\left(530 \mathrm{~kg}\right.$ per $\left.\mathrm{m}^{3}\right)$. The binder is comprised of PUZZOLANIT (HCEMENT) $\left(360 \mathrm{~kg}\right.$ per $\left.\mathrm{m}^{3}\right)$, water $\left(191 \mathrm{~kg}\right.$ per $\left.\mathrm{m}^{3}\right)$, and plasticizer in the amount of $1.4 \%\left(5.1 \mathrm{~kg}\right.$ per $\left.\mathrm{m}^{3}\right)$ of the weight of cement.

\subsection{Production of Test Specimens}

The production of test specimens according to the concrete mixture designs (see Section 2.3) took place in two stages (stage I and II). From each design ( $\mathrm{C}, \mathrm{CH}, \mathrm{H}), 4$ mixtures with a volume of $20 \mathrm{dm}^{3}$ were mixed. Within the two stages of the production of concrete test specimens based on industrial waste, $160 \mathrm{dm}^{3}$ of concrete mixture, 32 cubes with an edge of $150 \mathrm{~mm}$, and 6 prisms with dimensions of $100 \times 100 \times 400 \mathrm{~mm}^{3}$ were prepared according to each concrete mixture design. Thus, a total of $480 \mathrm{dm}^{3}$ of concrete mixture based on industrial waste, 96 cubes, and 18 prisms were produced. An M80 forced mixer (cyclone mixer) from FILAMOS, s.r.o. was used for the production of the concrete mixture (CZ).

The procedure for the production of fresh concrete was as follows: (1) batching of steel slag (CSS) of fraction $0 / 4 \mathrm{~mm}$ and $4 / 8 \mathrm{~mm}$ and $1 / 2$ the weight of mixing water (mixing time: $30 \mathrm{~s}$ ); (2) mixing of cement and stirring of the mixture for $1 \mathrm{~min}$; (3) batching the rest of the mixing water and mixing the mixture for $1 \mathrm{~min}$; (4) adding 2/3 of the plasticizer and mixing the mixture for $1 \mathrm{~min}$; (5) adding ACBFS blast furnace slag of fraction 8/16 $\mathrm{mm}$ and mixing the mixture for $1 \mathrm{~min}$; (6) adding the rest of the plasticizing admixture and mixing the mixture for $1 \mathrm{~min}$; and (7) adding ACBFS blast furnace slag of fraction 16/32 $\mathrm{mm}$ and mixing the mixture for $1 \mathrm{~min}$. The total time of one mix was $6 \mathrm{~min} 30 \mathrm{~s}$.

The filling of the test specimens (cubes and prisms) always took place in two layers. Each layer was compacted for $8 \mathrm{~s}$ on a VSB40 vibrating table. The total compaction time of concrete was $16 \mathrm{~s}$. After compacting, the top layer and the excess concrete were removed with a trowel and the surface was smoothed with a trowel to make it level with the surface of the mould. The test specimens were removed from the moulds on the second day after mixing and they were placed in a water bath at a temperature of $20{ }^{\circ} \mathrm{C}$ and in an outdoor environment.

\subsection{Placement of Test Specimens}

Test specimens from stage I of the production process were placed in a container in an aqueous environment with temperature control, where heating was provided by a heating 
cable. The water temperature in the test tank with the test specimens was $20^{\circ} \mathrm{C} \pm 2.0^{\circ} \mathrm{C}$ throughout the entire experiment. The specimens were placed in the tank for 7,28 , and 90 days in accordance with EN 12390-2 [33].

Test specimens made in stage II were placed in an outdoor environment of the company Považská cementáreň, a.s. in August, September, and October 2017. To define the outdoor environment, we present the highest and lowest temperatures during individual months (see Figures 2-4), where the grey line shows long-term averages for the given day. Furthermore, precipitation totals in individual months are shown in Figures 5-7.

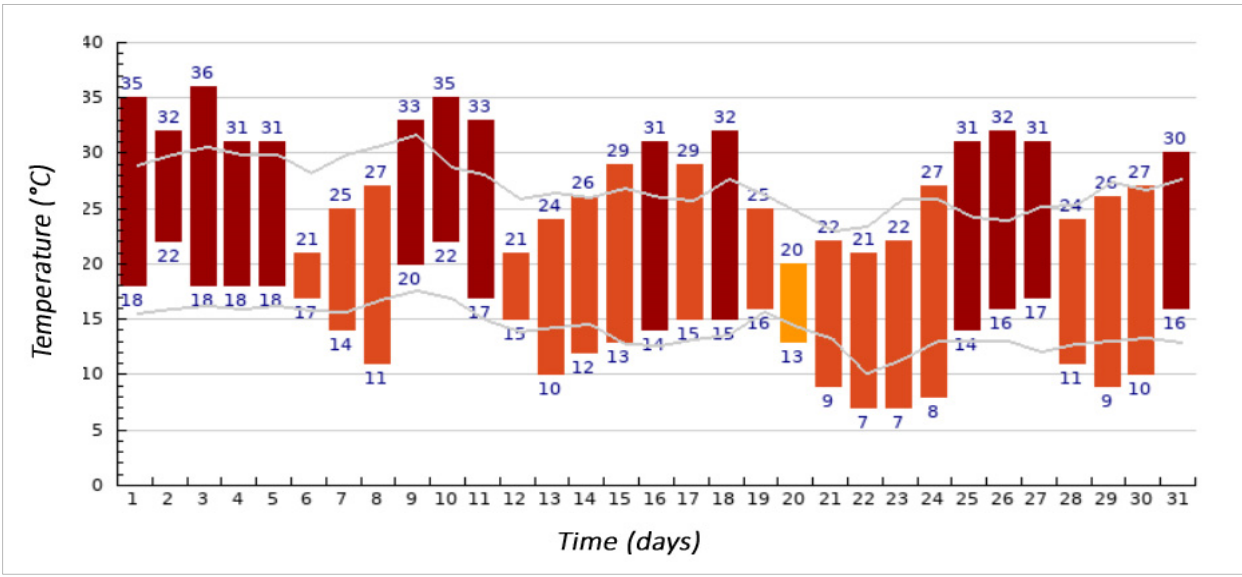

Figure 2. The highest and lowest temperatures in August 2017.

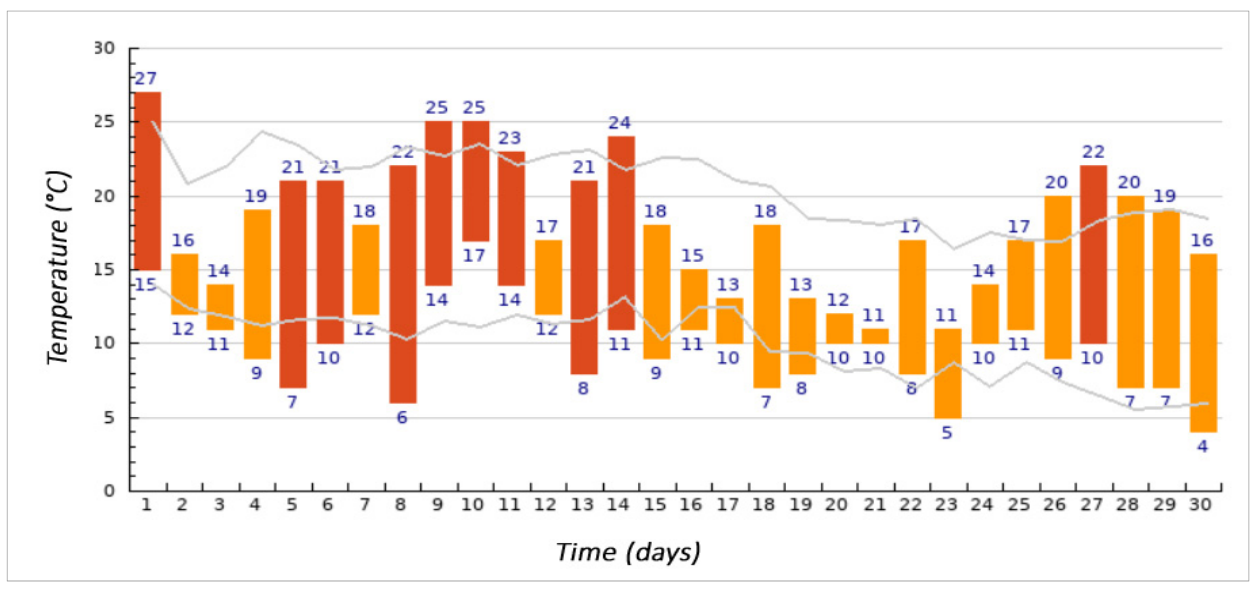

Figure 3. The highest and lowest temperatures in September 2017.

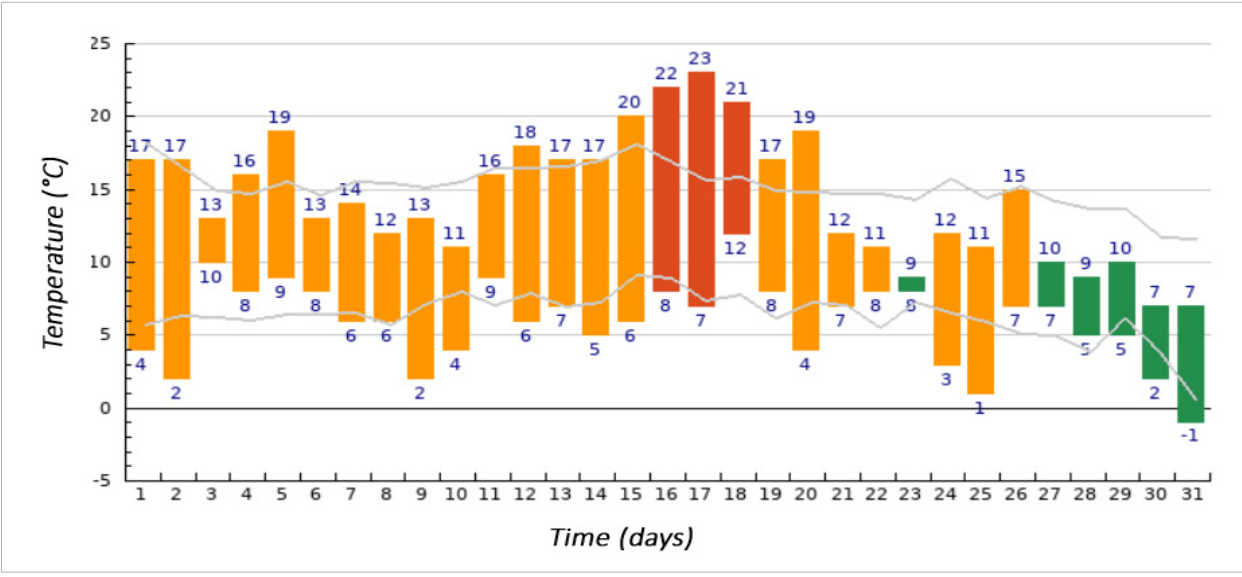

Figure 4. The highest and lowest temperatures in October 2017. 


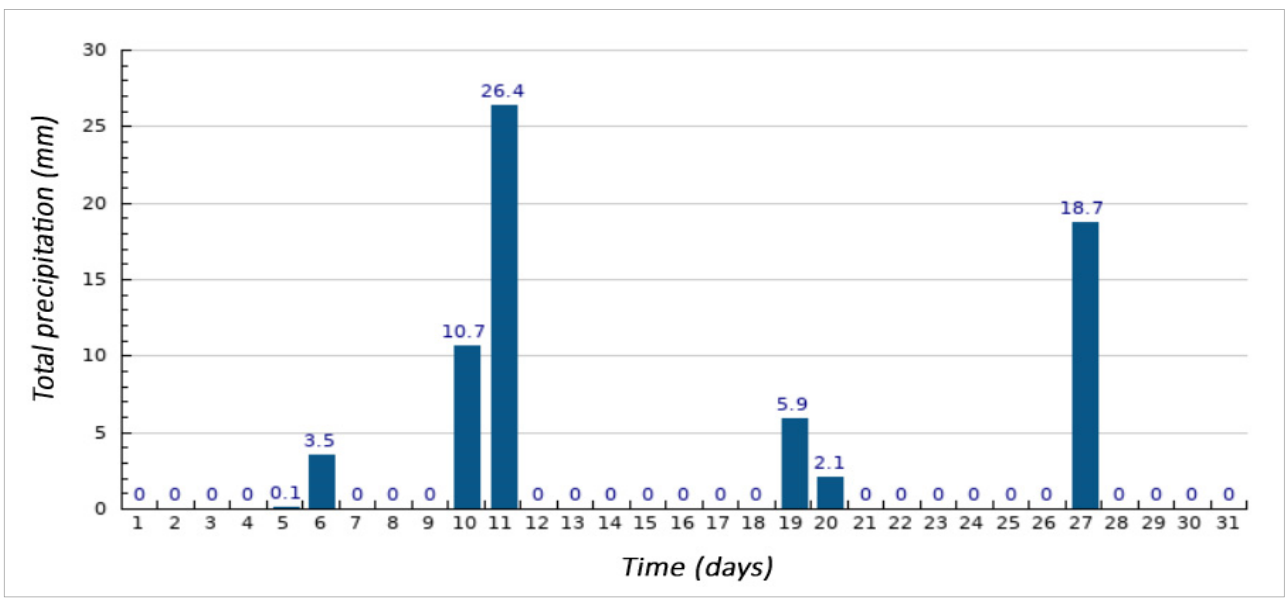

Figure 5. Total precipitation in August 2017.

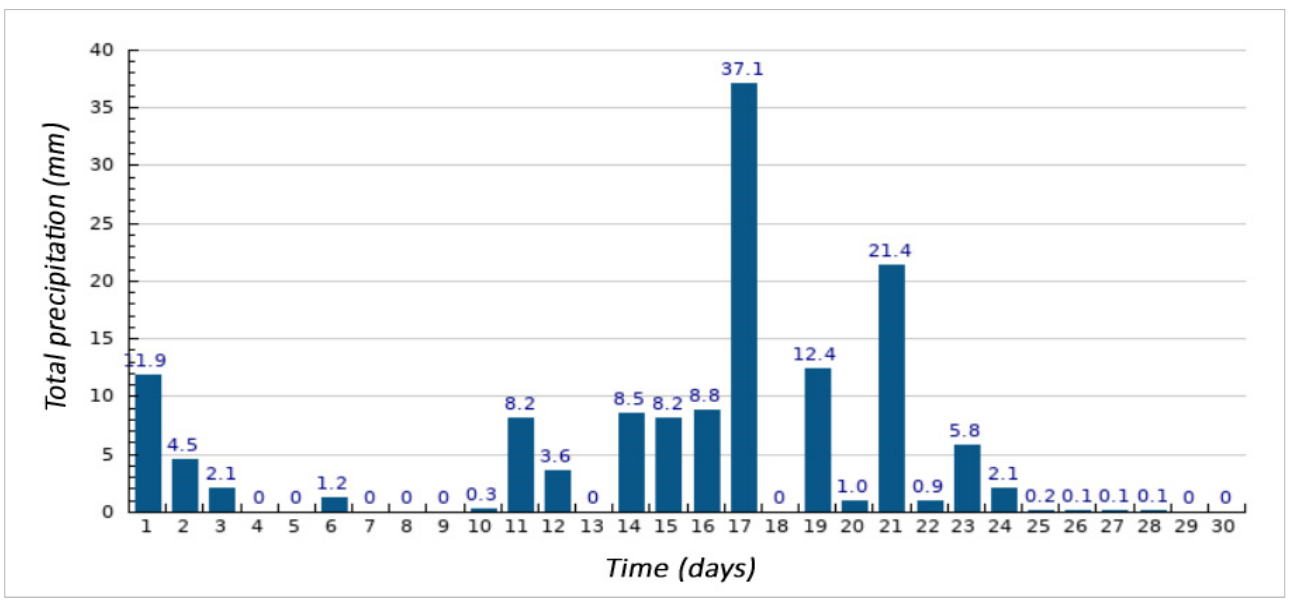

Figure 6. Total precipitation in September 2017.

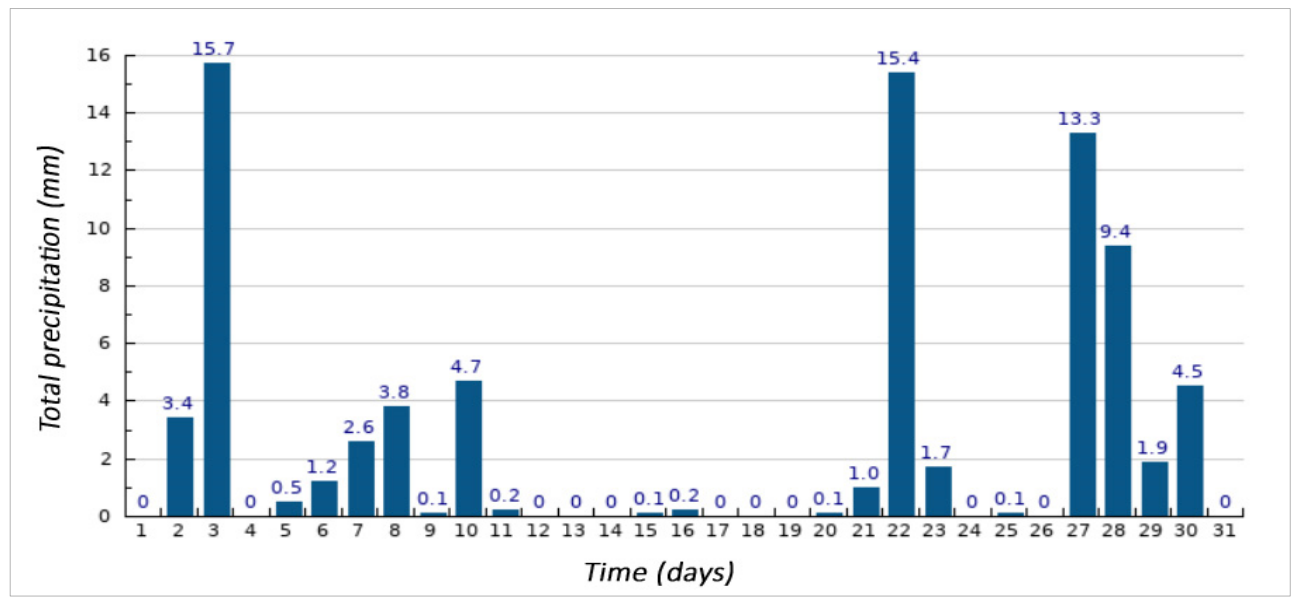

Figure 7. Total precipitation in October 2017.

Two methods for placing the test specimens were chosen in order to determine whether the environment in which the test specimens were placed affects the resulting properties of the steel-slag-based concrete (CSS) and air-cooled slag (ACBFS).

The third method for the placement of test specimens (with dimensions of $40 \times 40 \times$ $160 \mathrm{~mm}^{3}$ and cut out from a cube with an edge of $150 \mathrm{~mm}$ ) was chosen to be in sewage wastewater (in a septic tank) from the company Považská cementáreň, a.s. Table 8 shows 
the chemical composition of the sewage water as an aggressive environment for concrete based on by-products from a metallurgical plant.

Table 8. Composition of sewage water at a consumption of $150 \mathrm{~L} /$ person/day.

\begin{tabular}{cc}
\hline Parameter & Value (mg/L) \\
\hline BSK $_{5}$ & 400 \\
CHSK $_{\mathrm{Cr}}$ & 800 \\
$\mathrm{~N}_{\text {total }}$ & 70 \\
$\mathrm{P}_{\text {total }}$ & 15 \\
Solutes (RL) & 830 \\
Suspended solids (NL) & 370 \\
$\mathrm{NH}_{4}{ }^{+}$ & 45 \\
\hline
\end{tabular}

\subsection{Methodology of Concrete Properties Tests}

The properties of the fresh concrete mixtures were determined in accordance with applicable normative regulations. Determination of the density of a fresh concrete mixture was made according to EN 12350-6 [34], determination of the consistency of a fresh concrete mixture was made according to EN 12350-5 [35], and determination of the air content in a fresh concrete mixture was made according to EN 12350-7 [36]. Determination of the strength characteristics of hardened concrete was made according to EN 12390-3 [37] and the dynamic modulus of elasticity was determined according to CSN 731371 [38]. Image analysis of samples of concrete based on by-products from a metallurgical plant was performed on a DINO-LITE UNIVERSAL instrument.

\section{Results and Discussion}

\subsection{Rheological Properties of Cements}

To determine the optimal amount of PUZZOLANIT (H-CEMENT) in combination with Portland blended cement CEM II/B-S $42.5 \mathrm{~N}$, tests of the rheological properties of the cements used were performed. The rheological properties were determined on a Viskomat NT device of Schleibinger Geräte.

The result of the measurement is the measured torque $(\mathrm{Nmm})$ over time. The comparative cement was Portland blended cement (CEM II/B-S 42.5N). From Figure 8, it is clear that with the replacement of Portland blended cement by H-CEMENT in 20, 40, 60, and $80 \%$, the workability deteriorates, which may affect the properties of the fresh concrete mixture. Based on the presented results, it was found that with 20 and $40 \%$ replacement of CEM II/B-S $42.5 \mathrm{~N}$ by H-CEMENT, the workability was the least affected. Based on the obtained results on the rheology of the cements used for the production of the concrete mixture based on steel slag (CSS) and (ACBFS), a 30\% replacement of CEM II/BS 42.5N by H-CEMENT was chosen, where H-CEMENT was used as a mineral addition II of the kind denoted PUZZOLANIT. Determination of the rheology of the used cement was made according to the methodology of Považská cementáreň, a.s.

\subsection{Properties of a Fresh Concrete Mixture}

Determination of the properties of the fresh concrete mixture (consistency, air content, and density) was made in stages I and II of the production of test specimens. Within one stage, four mixtures were always made; within two stages, eight mixtures were made, i.e., the average value of the properties of the fresh concrete mixture was calculated from eight values. The results are presented in Table 9. 


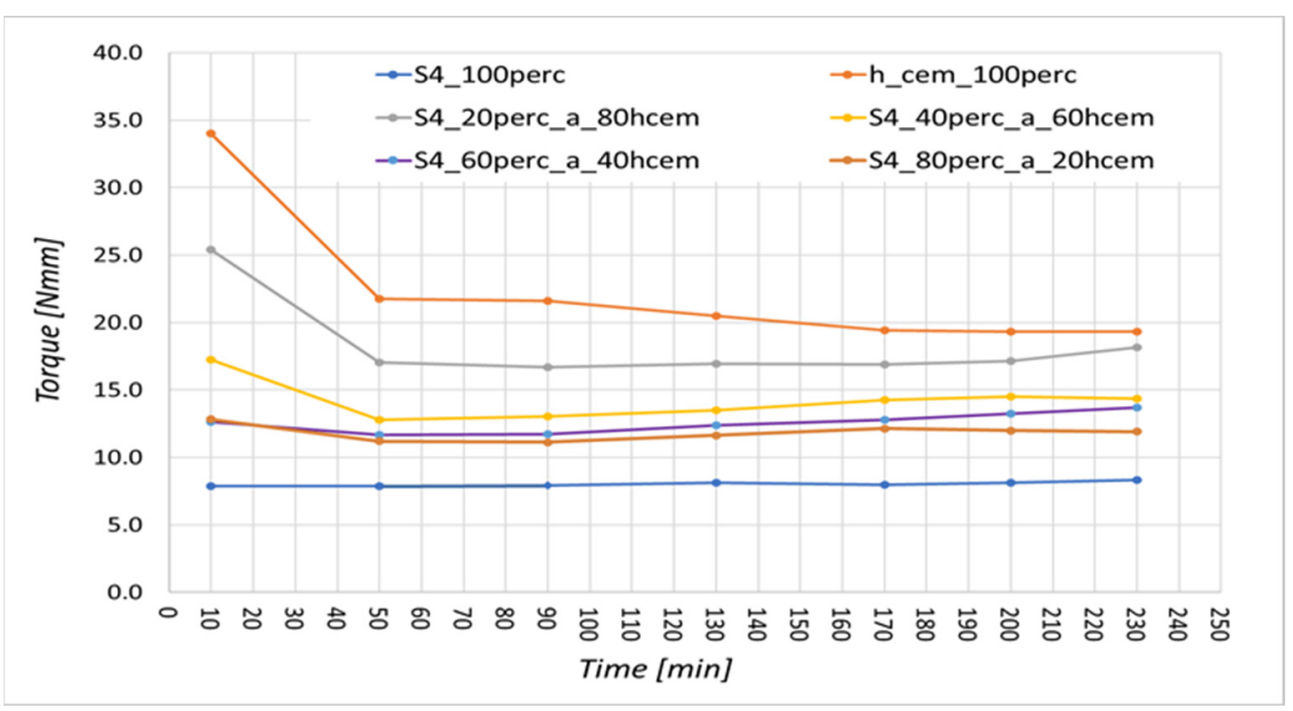

Figure 8. Dependence of torque on the time in minutes.

Table 9. Properties of fresh concrete mixture.

\begin{tabular}{cccc}
\hline Mix & Diffusion $(\mathbf{m m})$ & Air Content $\mathbf{( \% )}$ & Density $\mathbf{( k g / \mathbf { m } ^ { \mathbf { 3 } } )}$ \\
\hline $\mathrm{C}$ & $408( \pm 45)$ & $2.1( \pm 0.3)$ & $2656( \pm 31)$ \\
$\mathrm{CH}$ & $400( \pm 28)$ & $2.0( \pm 0.1)$ & $2653( \pm 14)$ \\
$\mathrm{H}$ & $333( \pm 25)$ & $2.2( \pm 0.3)$ & $2623( \pm 23)$ \\
\hline
\end{tabular}

The results in Table 9 show that:

(a) The diffusion values of the fresh concrete mixture correspond to a consistency F2 of 350-410 mm for mix C and $\mathrm{CH}$ and a consistency F1 $\leq 340 \mathrm{~mm}$ for mix $\mathrm{H}$. From the above, it is clear that when using H-CEMENT as a binder in the production of concrete based on steel slag (CSS) and air-cooled slag (ACBFS), it is necessary to take into account the reduction of the workability value of the fresh concrete mixture if the H-CEMENT dosing is in the same amount as CEM II/BS 42.5N. When using $\mathrm{H}-\mathrm{CEMENT}$ as an addition (PUZZOLANIT) in the amount of $30 \%$ in concrete, the consistency of the fresh concrete mixture will not be significantly affected.

(b) Regarding the air content in the fresh concrete mixture with steel slag (CSS) and aircooled slag (ACBFS) and gradual replacement of CEM II/B-S 42.5N using H-CEMENT as an addition (PUZZOLANIT) in the amount of $30 \%$ and $100 \%$ replacement by $\mathrm{H}-$ CEMENT, the change of the binder does not affect the air content in the fresh concrete mixture.

(c) The values of the density of the fresh concrete mixture demonstrate the suitability of using steel slag (CSS) and (ACBFS) as a 100\% substitute for natural aggregates and various types of binder, without the density of the fresh concrete mixture being significantly affected by the repeatability of the concrete mixture's production.

\subsection{Strength Characteristics of Concrete}

Figure 9 shows the results on cube strengths after 7, 28, and 90 days of aging of the test specimens from the first stage of production of test specimens, which were placed in an aqueous environment.

From the above picture, it can be seen that the placement in water suits the test specimens that were prepared using CEM II/B-S 42.5N (mix C) and CEM II/B-S 42.5N in combination with H-CEMENT (mix $\mathrm{CH}$ ). These test specimens show a gradual increase in cube strength after 7, 28, and 90 days of aging of the test specimens. This is also confirmed by the value of the coefficient of determination, which is $\mathrm{R}=0.98$ ( $\mathrm{mix} \mathrm{C}$ ) and $\mathrm{R}=0.96$ (mix CH). A very small and gradual increase in the strength of the concrete of test 
specimens placed in an aqueous environment was demonstrated for formula $\mathrm{H}$ (coefficient of determination $\mathrm{R}=0.55)$.

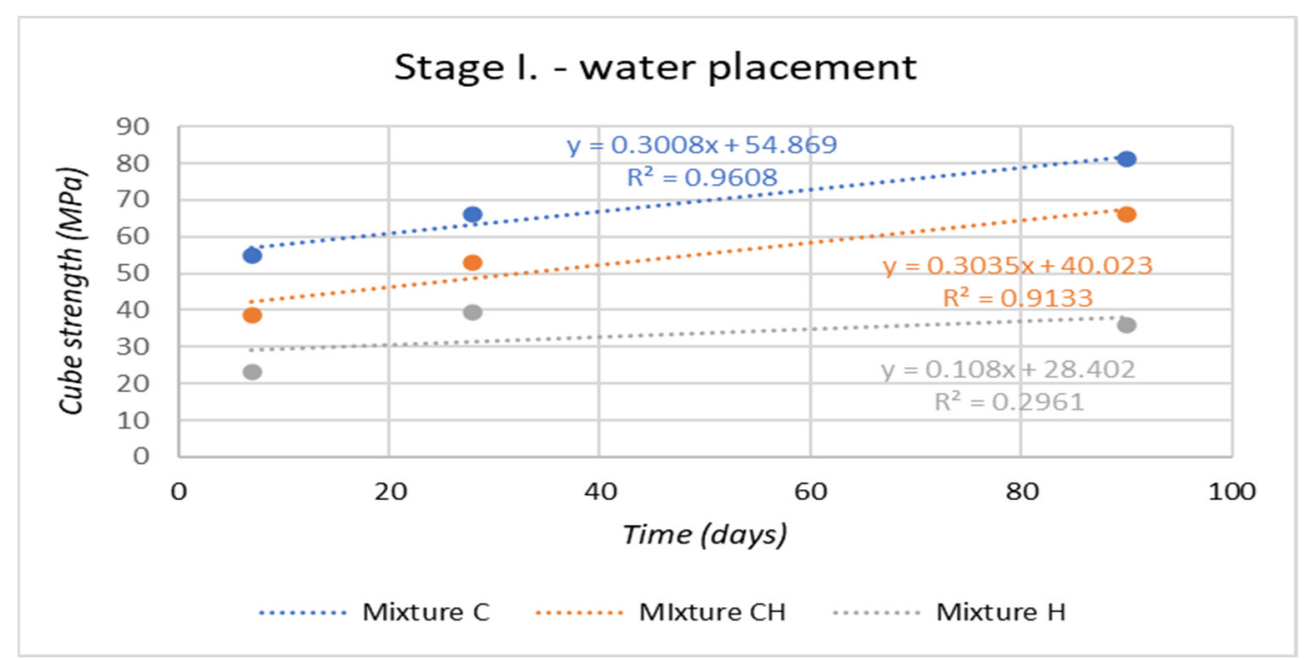

Figure 9. Cube strength of concrete according to experimental mixes-placement in water.

Figure 10 shows the results on cube strengths after 7, 28, and 90 days of aging of test specimens from the second stage of production of test specimens, which were placed outdoors. An increase in cube strengths is evident in all test specimens prepared according to the experimental mixture designs. However, when comparing the coefficient of determination of the experimental mixes, where the test specimens were placed in aqueous and outdoor environments, it is clear that the outdoor environment in which test specimens were placed caused the value of the coefficient of determination to decrease for mixture $\mathrm{C}$ to $\mathrm{R}=0.90$ and for mixture $\mathrm{CH}$ to $\mathrm{R}=0.86$. In contrast, an increase in the coefficient of determination was found in test specimens made from the H-CEMENT-based mixture $\mathrm{H}$ to the value $R=0.91$.

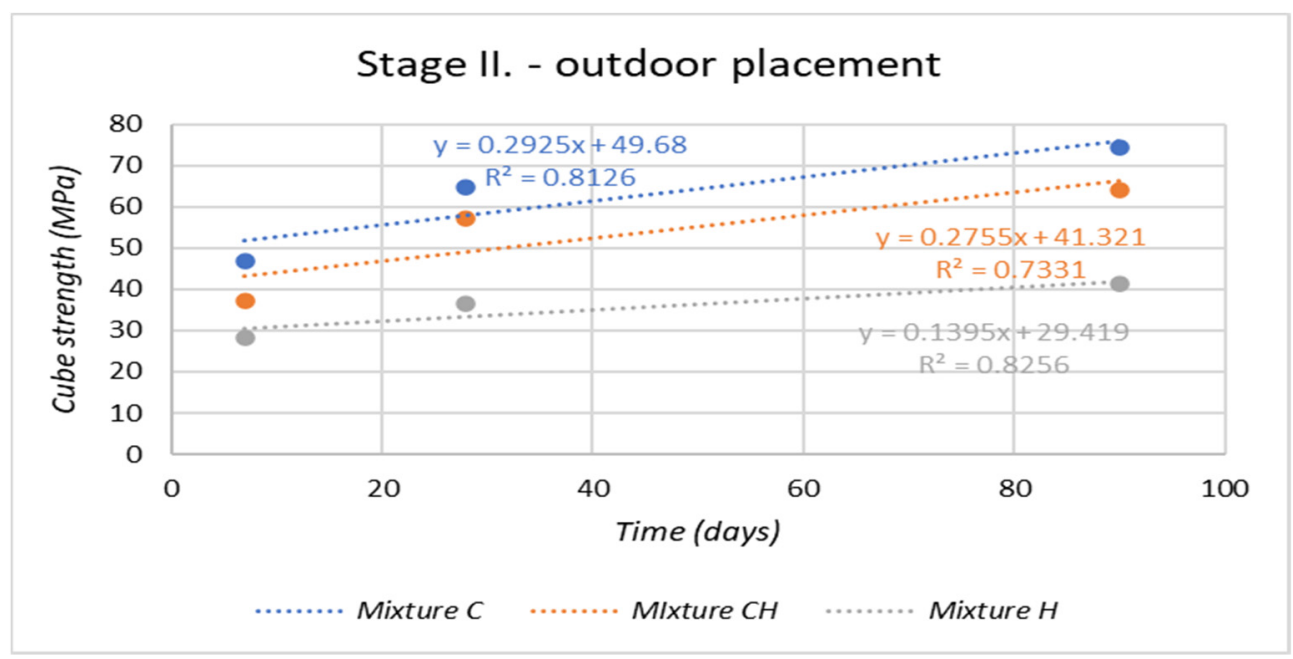

Figure 10. Cube strength of concrete according to experimental mixtures-placement in water.

Figures 11-13 present the development of cube strength at 7, 28, and 90 days of age of the test specimens placed in an aqueous environment and an outdoor environment depending on the substitution of the Portland blended cement CEM II/BS $42.5 \mathrm{~N}$ by hybrid $\mathrm{H}-\mathrm{CEMENT}$ in 30\% (mixture $\mathrm{CH}$ ) and $100 \%$ (mixture $\mathrm{H}$ ).

Figures 11-13 show that the replacement of the Portland blended cement CEM II/B-S $42.5 \mathrm{~N}$ with the hybrid cement H-CEMENT in combination with steel slag (CSS) and air- 
cooled slag (ACBFS) reduced the cube strength of the concrete. The influence of the outdoor environment for the placement of test specimens caused a decrease in cube strengths when using the Portland blended cement CEM II/B-S $42.5 \mathrm{~N}$ as a $100 \%$ binder component. When using $\mathrm{H}$-CEMENT as an addition (PUZZOLANIT) in the amount of $30 \%$ (mixture $\mathrm{CH}$ ), the influence of the outdoor environment on the cube strength decreased and the cube strengths equalized. After 28 days, an increase in cube strength was also found (see Figure 11). When H-CEMENT was used as a 100\% replacement for the Portland blended cement CEM II/B-S 42.5N (mix H), the placement of test specimens outdoors proved to be suitable in comparison with their placement in water. The outdoor environment caused an increase in the initial (7 days) and long-term (90 days) cube strengths.

Figure 14 presents the results on the strength of the concrete based on steel slag (CSS) and air-cooled slag (ACBFS) prepared according to the experimental formulas. The flexural strength of the concrete was tested on prisms with dimensions of $100 \times 100 \times 400 \mathrm{~mm}^{3}$ after 28 days of aging of the test specimens. It is evident that the outdoor placement of the test specimens caused the flexural strength of all experimental mixtures to be equalized $(\mathrm{C}, \mathrm{CH}$ and $\mathrm{H})$. In the aqueous environment, the trend of a decrease in flexural strength is evident with a coefficient of determination value of $R=0.80$.

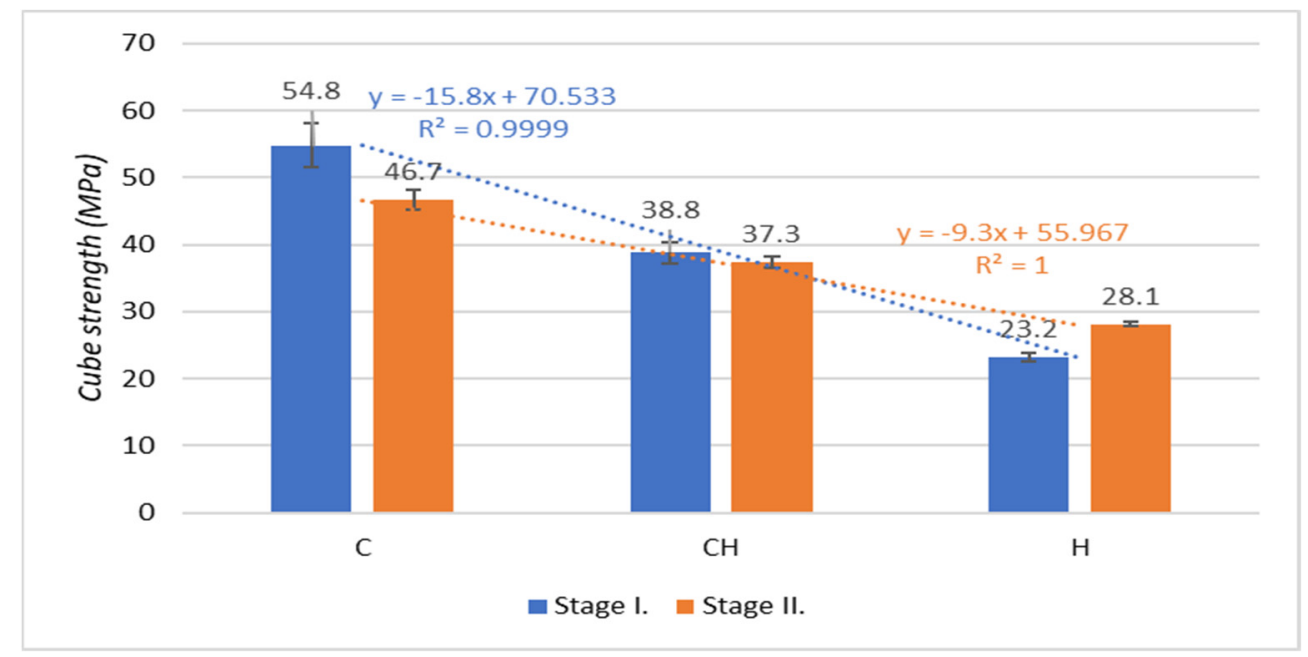

Figure 11. Cube strength after 7 days (aqueous and outdoor environment).

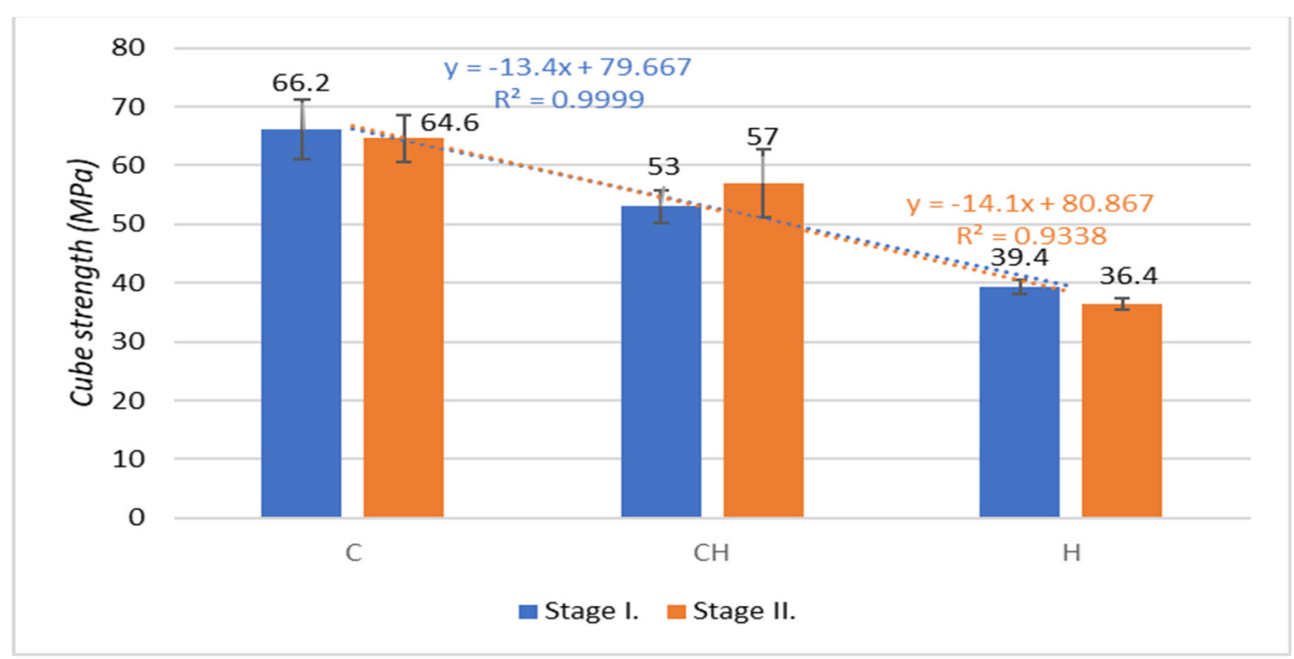

Figure 12. Cube strength after 28 days (aqueous and outdoor environment). 


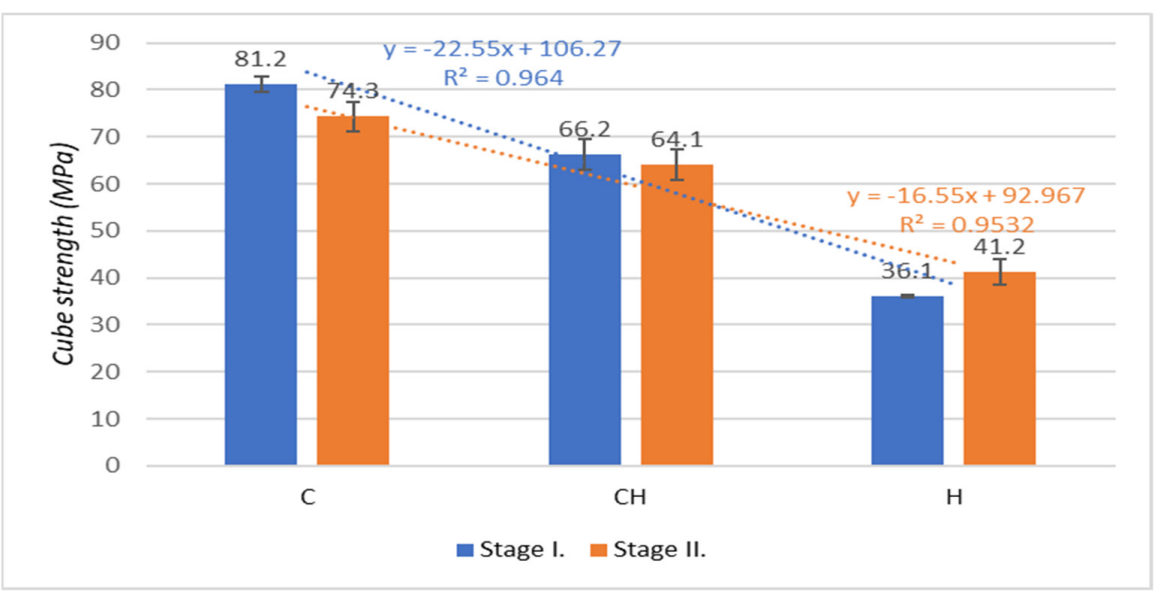

Figure 13. Cube strength after 90 days (aqueous and outdoor environment).

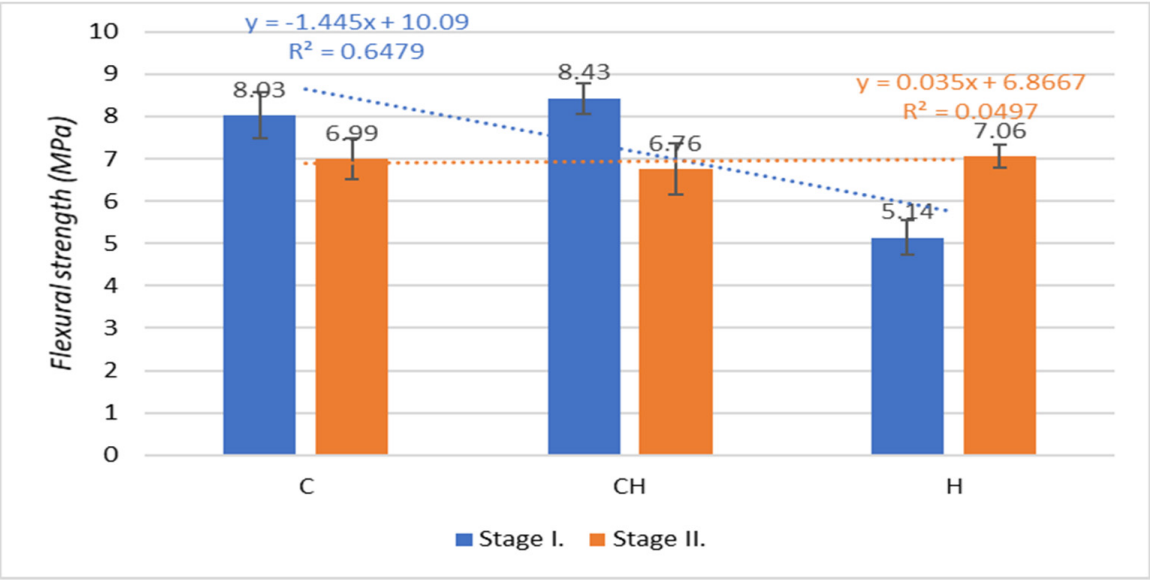

Figure 14. Flexural strength after 28 days (aqueous and outdoor environment).

Figure 15 presents the dependence of the dynamic modulus of elasticity on the cube strength. The dynamic modulus of elasticity was determined after 28 days on prisms with dimensions of $100 \times 100 \times 400 \mathrm{~mm}^{3}$. We found that the test specimens that were placed in an aqueous environment showed a dependence where an increase in compressive strength is accompanied by an increase in the value of the dynamic modulus of elasticity with the value of the coefficient of determination $R=0.91$. For test specimens that were placed outdoors, a slight increase in the dynamic modulus of elasticity with the value of the coefficient of determination $\mathrm{R}=0.95$ is evident.

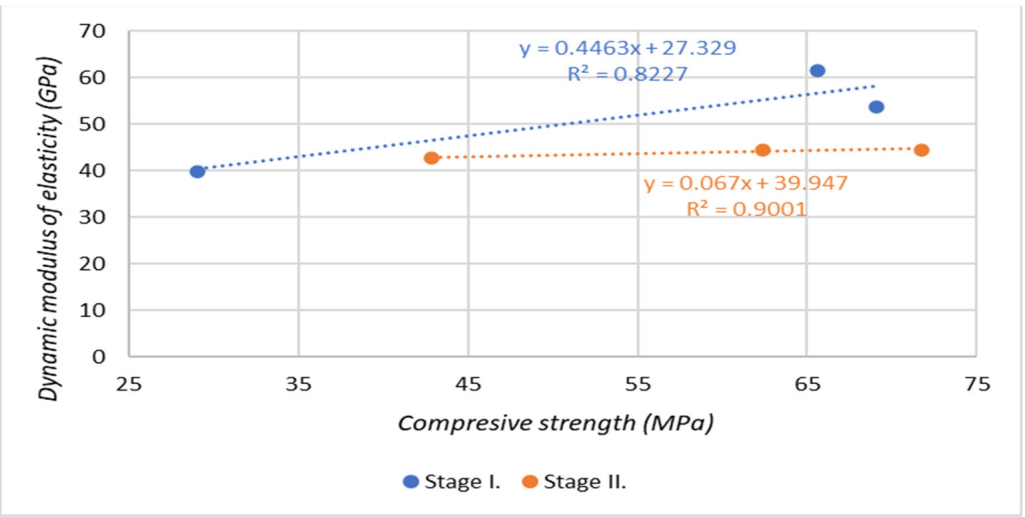

Figure 15. Dependence of the dynamic modulus of elasticity on cube strength (aqueous and outdoor environment). 


\subsection{Image Analysis of Concrete}

An image analysis was performed on the test specimens marked $\mathrm{C}, \mathrm{CH}$, and $\mathrm{H}$, which were prepared according to the formulas shown in Section 2.3. The test specimens for the image analysis were 3 years old and were placed in sewage water produced by the company Považská cementáreň, a.s. and an outdoor environment. The aim of the image analysis was to define the grains of steel and blast furnace slag in the concrete structure and to study the contact zones between the grains of steel and blast furnace slag and cement putty.

From the results of the image analysis (see Figure 16), the following conclusions can be drawn:

- We were able to define steel slag grains (CSS) and blast furnace slag grains (ACBFS) in the concrete structure.

- Cement paste was also formed by small particles of steel slag (CSS) and blast furnace slag (ACBFS).

- $\quad$ Placing concrete samples outdoors for 3 years did not disrupt the concrete structure.

- Placing concrete samples in an aggressive environment (in wastewater) for 3 years did not disrupt the concrete structure. The above does not apply to the concrete sample marked H-sw. Cracks in the cement paste and disturbances in the contact zone between the steel slag grain (CSS) and the cement paste are visible here.

- None of the samples (except for the H-sw sample) shows any disturbance of the contact zone (ITZ) between the blast furnace slag grain (ACBFS), the steel slag (CSS), and the cement paste.

- None of the samples (except the H-sw sample) shows any cracking of the cement paste. This does not apply to the H-sw sample.
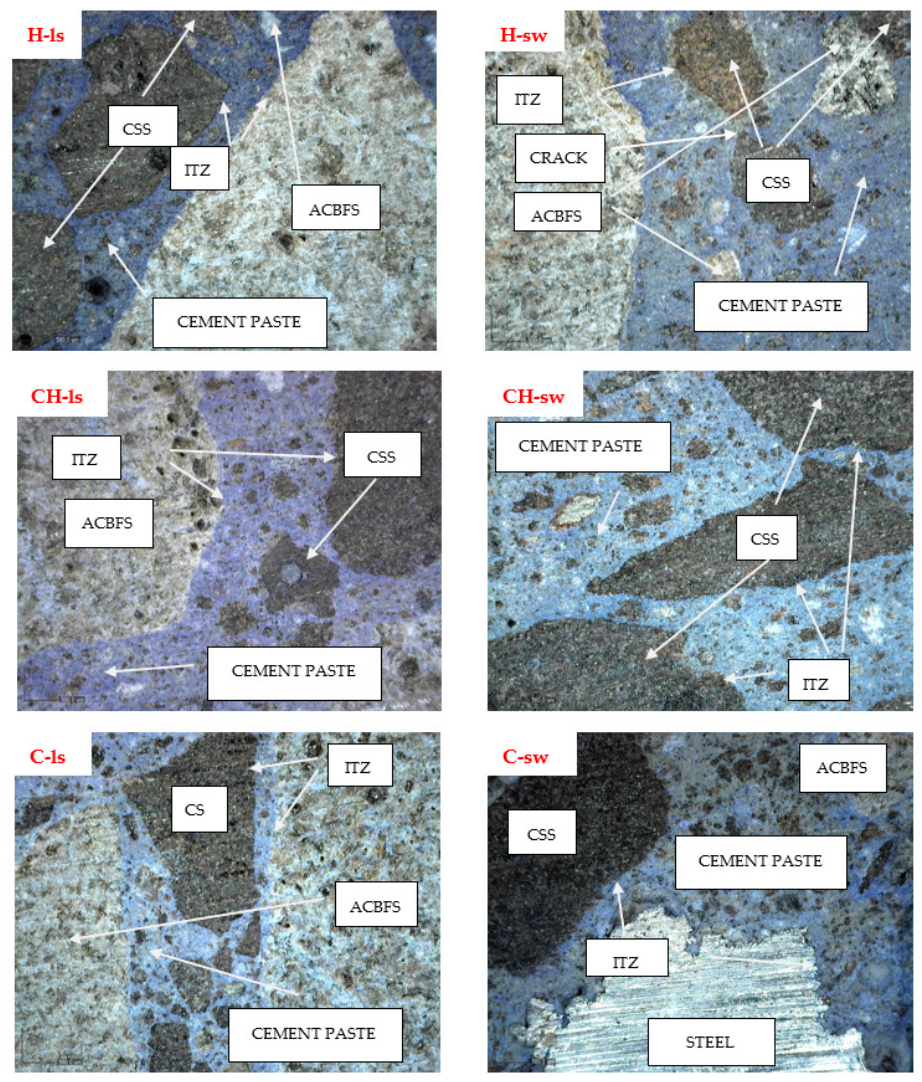

Figure 16. Images of concrete based on blast furnace slag (ACBFS) and steel slag (CSS) magnified $62 \times$. The samples marked $\mathrm{H}, \mathrm{CH}$, and C-ls were placed outdoors environment. The samples marked $\mathrm{H}, \mathrm{CH}$, and $\mathrm{C}$-sw were placed in sewage water. 


\section{Conclusions}

The primary aim of this experimental research was to prove the possibility of using steel slag (CSS) of fraction $0 / 8 \mathrm{~mm}$ in combination with air-cooled slag (ACBFS) of fraction $8 / 32 \mathrm{~mm}$ in the development of concrete mixture designs as a $100 \%$ replacement for natural aggregates in combination with Portland blended cement (CEM II/B-S 42.5N) and hybrid cement (H-CEMENT) from the company Považská cementáreň, a.s. Another aim of this research was to determine the influence of the binder on the properties of a fresh concrete mixture and hardened concrete placed in aqueous and outdoor environments. Based on the results obtained, the following conclusions can be drawn:

- Use of steel slag (CSS) of $0 / 8 \mathrm{~mm}$ and air-cooled slag (ACBFS) of 8/32 $\mathrm{mm}$ in the production of concrete mixtures does not affect the air content in a fresh concrete mixture. For the proposed mixtures $(\mathrm{C}, \mathrm{CH}$, and $\mathrm{H})$, the air content ranged from 2.0 to $2.2 \%$.

- By using steel slag (CSS) of $0 / 8 \mathrm{~mm}$ and air-cooled slag (ACBFS) of $8 / 32 \mathrm{~mm}$ in the production of a concrete mixture, it is possible to ensure the repeatability of the production of the concrete mixture without significantly affecting the values of the density of the fresh concrete mixture. The density of fresh concrete was $2623-2656 \mathrm{~kg} / \mathrm{m}^{3}$.

- The consistency of a fresh concrete mixture using steel slag (CSS) of $0 / 8 \mathrm{~mm}$ and air-cooled slag (ACBFS) of $8 / 32 \mathrm{~mm}$ depends on the type of binder used while maintaining the same quantity. The consistency of the fresh concrete mix can be modified with a plasticizing admixture while maintaining the water coefficient.

- When using a combination of steel slag (CSS) of $0 / 8 \mathrm{~mm}$ and air-cooled slag (ACBFS) of $8 / 32 \mathrm{~mm}$ we can prepare concrete with a cube strength of $40-80 \mathrm{MPa}$ after 90 days and a flexural strength after 90 days of 5-8 MPa depending on the binder used. The used ratio of CSS to ACBS was 50:50 based on previous pilot outdoor applications.

- The experiment showed that the placement of test specimens in aqueous and outdoor environments has an effect on the strength characteristics of concrete based on byproducts from a metallurgical plant. The placement of the test specimens in outdoor environments reduced the strength compared with aqueous environments. This applies to the cube strengths determined after 90 days for mixture $\mathrm{C}$ (an $8 \%$ reduction) and $\mathrm{CH}$ (a $3 \%$ reduction).

- The H-CEMENT proved its worth, especially in those test specimens that were placed outdoors. After 90 days, the cubic strength increased by $14 \%$ and the flexural strength after 28 days increased by $37 \%$ compared with the cube strength and flexural strength of the test specimens placed in an aqueous environment.

- The results of the image analysis show that H-CEMENT (as a 100\% binder) is not suitable for concretes based on by-products from a metallurgical plant that will be exposed to aggressive environments (wastewater). For concretes placed in aggressive environments (wastewater), it is possible to use $\mathrm{H}$-CEMENT as a $30 \%$ addition (PUZZOLANIT, see mixture $\mathrm{CH}$ in Section 2.3).

- When using H-CEMENT in the production of a concrete mixture based on by-products from a metallurgical plant, $\mathrm{CO}_{2}$ emissions will be reduced in comparison with $\mathrm{CEM}$ II/B-S $42.5 \mathrm{~N}$ by a minimum of $50 \%$ in terms of clinker content.

- The use of by-products from a metallurgical plant (steel slag and air-cooled blast furnace slag) in the production of concrete will result in a reduction in the cost of producing $1 \mathrm{~m}^{3}$ of the concrete mixture, save natural resources, and produce an increase in the density of the fresh concrete mixture and hardened concrete.

- The results have practical implications for the circular economy.

- Our ongoing research is focused on a pilot study on concreting under ambient conditions.

Author Contributions: Conceptualization, P.M. and V.V.; methodology, P.M., V.V. and B.C.; validation, V.V. and B.C.; formal analysis, V.V.; investigation, V.V. and B.C.; resources, P.M.; data curation, V.V. and B.C.; writing-original draft preparation, V.V. and B.C.; writing-review and editing, P.M.; funding acquisition, P.M. All authors have read and agreed to the published version of the manuscript. 
Funding: This research was funded by Považská cementáreň, a.s., ul. Janka Král’a, 01863 Ladce, Slovakia.

Acknowledgments: This article was written in collaboration with the laboratory of Považská cementáreň, a.s., ul. Janka Král'a, 01863 Ladce, Slovakia. Our thanks go to Ing. Katarina Martauzová and Helena Habánková.

Conflicts of Interest: The authors declare no conflict of interest.

\section{References}

1. Peter, J. Koros Dusts, scale, slags, sludges...not wastes, but sources of profits. Metall Mater. Trans. B 2003, 34, 769-779. [CrossRef]

2. Martauz, P.; Vaclavik, V.; Cvopa, B. The use of steel slag in concrete. In IOP Conference Series: Earth and Environmental Science; IOP Publishing: Bristol, UK, 2017; Volume 92.

3. Faleschini, F.; Alejandro Fernández-Ruíz, M.; Zanini, M.A.; Brunelli, K.; Pellegrino, C.; Hernández-Montes, E. High performance concrete with electric arc furnace slag as aggregate: Mechanical and durability properties. Constr. Build. Mater. 2015, 101, 113-121. [CrossRef]

4. Pellegrino, C.; Gaddo, V. Mechanical and durability characteristics of concrete containing EAF slag as aggregate. Cem. Concr. Compos. 2009, 31, 663-671. [CrossRef]

5. Abu-Eishah, S.I.; El-Dieb, A.S.; Bedir, M.S. Performance of concrete mixtures made with electric arc furnace (EAF) steel slag aggregate produced in the Arabian Gulf region. Constr. Build. Mater. 2012, 34, 249-256. [CrossRef]

6. Papayianni, I.; Anastasiou, E. Production of high-strength concrete using high volume of industrial by-products. Constr. Build. Mater. 2010, 24, 1412-1417. [CrossRef]

7. Etxeberria, M.; Pacheco, C.; Meneses, J.M.; Berridi, I. Properties of concrete using metallurgical industrial by-products as aggregates. Constr. Build. Mater. 2010, 24, 1594-1600. [CrossRef]

8. Polanco, J.A.; Manso, J.M.; Setien, J.; Gonzalez, J.J. Strength and Durability of Concrete Made with Electric Steelmaking Slag. Mater. J. 2011, 108, 196-203. [CrossRef]

9. San-José, J.T.; Vegas, I.; Arribas, I.; Marcos, I. The performance of steel-making slag concretes in the hardened state. Mater. Des. 2014, 60, 612-619. [CrossRef]

10. Al-Negheimish, A.I.; Al-Sugair, F.H.; Al-Zaid, R.Z. Utilization of Local Steelmaking Slag in Concrete. J. King Saud Univ. Eng. Sci. 1997, 9, 39-54. [CrossRef]

11. Pellegrino, C.; Cavagnis, P.; Faleschini, F.; Brunelli, K. Properties of concretes with Black/Oxidizing Electric Arc Furnace slag aggregate. Cem. Concr. Compos. 2013, 37, 232-240. [CrossRef]

12. Sheen, Y.-N.; Le, D.-H.; Sun, T.-H. Innovative usages of stainless steel slags in developing self-compacting concrete. Constr. Build. Mater. 2015, 101, 268-276. [CrossRef]

13. Kriskova, L.; Pontikes, Y.; Cizer, Ö.; Mertens, G.; Veulemans, W.; Geysen, D.; Jones, P.T.; Vandewalle, L.; Van Balen, K.; Blanpain, B. Effect of mechanical activation on the hydraulic properties of stainless steel slags. Cem. Concr. Res. 2012, 42, 778-788. [CrossRef]

14. Dong, Q.; Wang, G.; Chen, X.; Tan, J.; Gu, X. Recycling of steel slag aggregate in portland cement concrete: An overview. J. Clean. Prod. 2021, 282, 124447. [CrossRef]

15. Gencel, O.; Karadag, O.; Oren, O.H.; Bilir, T. Steel slag and its applications in cement and concrete technology: A review. Constr. Build. Mater. 2021, 283, 122783. [CrossRef]

16. Mengasini, L.; Mavroulidou, M.; Gunn, M.J. Alkali-activated concrete mixes with ground granulated blast furnace slag and paper sludge ash in seawater environments. Sustain. Chem. Pharm. 2021, 20, 100380. [CrossRef]

17. Wei, X.; Li, D.; Ming, F.; Yang, C.; Chen, L.; Liu, Y. Influence of low-temperature curing on the mechanical strength, hydration process, and microstructure of alkali-activated fly ash and ground granulated blast furnace slag mortar. Constr. Build. Mater. 2021, 269, 121811. [CrossRef]

18. Kranthi Vijaya, S.; Jagadeeswari, K.; Lal Mohiddin, S.; Srinivas, K. Stiffness determination of alkali activated ground granulated blast furnace slag based geo-polymer concrete. Mater. Today Proc. 2020. [CrossRef]

19. Gholampour, A.; Zheng, J.; Ozbakkaloglu, T. Development of waste-based concretes containing foundry sand, recycled fine aggregate, ground granulated blast furnace slag and fly ash. Constr. Build. Mater. 2021, 267, 121004. [CrossRef]

20. Abhishek, P.; Ramachandra, P.; Niranjan, P.S. Use of recycled concrete aggregate and granulated blast furnace slag in selfcompacting concrete. Mater. Today Proc. 2020, 42, 479-486. [CrossRef]

21. Marinković, S.; Radonjanin, V.; Malešev, M.; Ignjatović, I. Comparative environmental assessment of natural and recycled aggregate concrete. Waste Manag. 2010, 30, 2255-2264. [CrossRef]

22. Guo, H.; Shi, C.; Guan, X.; Zhu, J.; Ding, Y.; Ling, T.-C.; Zhang, H.; Wang, Y. Durability of recycled aggregate concrete-A review. Cem. Concr. Compos. 2018, 89, 251-259. [CrossRef]

23. Ajdukiewicz, A.; Kliszczewicz, A. Influence of recycled aggregates on mechanical properties of HS/HPC. Cem. Concr. Compos. 2002, 24, 269-279. [CrossRef]

24. Corinaldesi, V. Mechanical and elastic behaviour of concretes made of recycled-concrete coarse aggregates. Constr. Build. Mater. 2010, 24, 1616-1620. [CrossRef]

25. Kawahigashi, T. Deterioration Mechanism and Estimation of Durability of Reinforced Concrete in Marine Environment: 5-year Exposure. Sci. Technol. 2001, 13, 31-38. 
26. Shi, C. Steel Slag-Its Production, Processing, Characteristics, and Cementitious Properties. J. Mater. Civ. Eng. 2004, 16, 230-236. [CrossRef]

27. Kourounis, S.; Tsivilis, S.; Tsakiridis, P.E.; Papadimitriou, G.D.; Tsibouki, Z. Properties and hydration of blended cements with steelmaking slag. Cem. Concr. Res. 2007, 37, 815-822. [CrossRef]

28. Zhang, T.; Yu, Q.; Wei, J.; Li, J.; Zhang, P. Preparation of high performance blended cements and reclamation of iron concentrate from basic oxygen furnace steel slag. Resour. Conserv. Recycl. 2011, 56, 48-55. [CrossRef]

29. Martauz, P.; Václavík, V.; Cvopa, B. The Properties of Concrete Based on Steel Slag as a By-Product of Metallurgical Production. Available online: https:/ / www.scientific.net/KEM.838.10 (accessed on 7 February 2021).

30. EN 1097-6 Tests for Mechanical and Physical Properties of Aggregates_Part 6: Determination of Particle Density and Water Absorption; Czech Office for Standards, Metrology and Testing: Prague, Czech Republic, 2014.

31. EN 1097-3 Tests for Mechanical and Physical Properties of Aggregates_Part 3: Determination of Loose Bulk Density and Voids; Czech Office for Standards, Metrology and Testing: Prague, Czech Republic, 1999.

32. EN 933-1 Tests for Geometrical Properties of Aggregates-Part 1: Determination of Particle Size Distribution-Sieving Method; Czech Office for Standards, Metrology and Testing: Prague, Czech Republic, 2012.

33. Bhutta, M.A.R.; Maruya, T.; Tsuruta, K. Use of polymer-impregnated concrete permanent form in marine environment: 10-year outdoor exposure in Saudi Arabia. Constr. Build. Mater. 2013, 43, 50-57. [CrossRef]

34. TEN 12350-6 Testing Fresh Concrete_Part 6: Density; Czech Office for Standards, Metrology and Testing: Prague, Czech Republic, 2020.

35. EN 12350-5 Testing Fresh Concrete-Part 5: Flow Table Test; Czech Office for Standards, Metrology and Testing: Prague, Czech Republic, 2020.

36. EN 12350-7 Testing Fresh Concrete—Part 7: Air content_Pressure Methods; Czech Office for Standards, Metrology and Testing: Prague, Czech Republic, 2020.

37. EN 12390-2 Testing Hardened Concrete_Part 2: Making and Curing Specimens for Strength Tests; Czech Office for Standards, Metrology and Testing: Prague, Czech Republic, 2020.

38. CSN 731371 Non-Destructive Testing of Concrete-Method of Ultrasonic Pulse Testing of Concrete; Czech Office for Standards, Metrology and Testing: Prague, Czech Republic, 2011. 